\title{
THE STAR OF BETHLEHEM, A COMET IN 5 BC AND THE DATE OF CHRIST'S BIRTH ${ }^{1}$
}

\author{
Colin J. Humphreys
}

\section{Introduction}

The star of Bethlehem has been considered either to be mythical or a miraculous object beyond the bounds of scientific explanation or a real astronomical phenomenon. ${ }^{2}$ The question of whether a celestial phenomenon reported in ancient literature in an historical context was a real astronomical object is one which occurs quite frequently. In all such cases it seems best to consider as a working hypothesis that the report is correct and to investigate whether any astronomical phenomenon exists which fits the report. Thus, tentatively, we take seriously the references in Matthew's gospel and in other ancient literature to the star of Bethlehem which is stated to have appeared near the time of the birth of Christ.

If an astronomical object can be identified with the characteristics described in Matthew and other ancient manuscripts, this information may throw light on the long standing problem of the date of the Nativity. In AD 525 a Roman scholar and monk, Dionysius Exiguus, fixed the AD origin of our present calendar (Anno Domini $=$ in the year of our Lord) so that Jesus was circumcised in the year AD 1 on 1 January (8 days, counting inclusively, after his birth on 25 December the previous year). More recently dates ranging

${ }^{1}$ The present paper is a revision of an article published in the Quarterly Journal of the Royal Astronomical Society 32 (1991) 389-407 and was given as a lecture at the Cambridge Philosophical Society on 11 November 1991. The author is grateful to W.G. Waddington for illuminating discussions and to A. Bole, O. Edwards, Ho Peng-Yoke, H.W. Hoehner, D. Hughes, M. Loewe, A.R. Millard, C. Russell, J. Shanklin and B.W. Winter for very helpful comments and for critical reading of the manuscript.

2Some excellent reviews exist. See D. Hughes, 'The Star of Bethlehem', Nature 264 (1976) 513-517; idem, The Star of Bethlehem Mystery (London, Dent 1979); J. Finegan, Handbook of Biblical Chronology (Princeton, University Press 1964). 
from $20 \mathrm{BC}$ to $\mathrm{AD} 10$ have been given for the year of the Nativity. ${ }^{3}$ Concerning the day, although 25 December is firmly fixed in our calendar, this is unlikely if the arguments in the present paper are accepted. In this article we consider a combination of astronomical and historical evidence which may be used to identify the star of Bethlehem and to determine the date of the Nativity.

The earliest known account of the star of Bethlehem is in Matthew 2:1-12. Most scholars accept that the final text of this gospel may have been composed in about AD 80 from sources written in earlier times. Presumably one of these sources recorded the star of Bethlehem and the visit of the Magi. The account in Matthew describes how the Magi saw a star which they believed heralded the birth of the Messiahking of the Jews. They travelled to Jerusalem and informed King Herod of the time when the star appeared, which indicates that the star was not a customary sight. The advisers of Herod told the Magi that, according to the prophesy of Micah, the Messiah should be born in Bethlehem, so the Magi journeyed there. The star moved before them and 'stood over' Bethlehem. The Magi found the place where the child was and presented him with gifts.

There are key questions arising from the account in Matthew's gospel, and other ancient literature, of the star of Bethlehem which the following discussion will attempt to answer: Who were the Magi? Is there a known astronomical phenomenon which fits the account; what induced the Magi to embark on their journey? Can astronomy be used to solve the long-standing problem of the date of the birth of Christ?

\section{The Magi}

The tradition that the Magi were kings dates from the sixth century $\mathrm{AD}$, and is almost certainly legendary. According to Herodotus, ${ }^{4}$ Magi existed in Persia in the sixth century BC, they were a priestly group among the Medes who performed religious ceremonies and interpreted signs and portents. Persia (now Iran) conquered neighbouring Mesopotamia (now Iraq) and from the fourth century BC onwards Magi were increasingly associated with astronomy and astrology, the

3Finegan, op. cit., Hughes, op. cit., (1979).

${ }^{4}$ Herodotus 1:101. 
observation and the 'interpretation' of the stars being closely related in ancient times and Babylon (in Mesopotamia) became the centre of ancient astronomy and astrology. In about 586 $\mathrm{BC}$ the Babylonians sacked Jerusalem and took the Jews into Exile. From the time of the Exile onwards Babylon contained a strong Jewish colony, and the knowledge of the Jewish prophecies of a Saviour-King, the Messiah, may have been well-known to the Babylonians and to the Magi.

In the Hellenistic age some of the Magi left Babylon and travelled to neighbouring countries to teach and practise astronomy/astrology, which was a core educational subject in the ancient world. 5 Thus the first century AD Jewish scholar Philo of Alexandria stated that the student of astronomy perceived 'timely signs of coming events' since 'the stars were made for signs' ${ }^{6}$ There is a strong tradition that the Magi who visited Jesus came from Arabia (now Saudi Arabia), which lies between Mesopotamia and Palestine. Thus in about AD 160 Justin Martyr wrote 'Magi from Arabia came to him [Herod]' and in about AD 96 Clement of Rome $^{7}$ associated frankincense and myrrh, two of the gifts of the Magi, with 'the East, that is the districts near Arabia'. We conclude that the Magi who saw the star of Bethlehem were astronomers/astrologers, who may have been familiar with the Jewish prophecies of a SaviourKing, and who probably came from Arabia or Mesopotamia, countries to the east of Palestine. Matthew 2:1 simply states 'Magi from the East arrived in Jerusalem'. It is important to realise that there are many references in ancient literature to Magi visiting kings and emperors in other countries. For example, Tiridates, the King of Armenia, led a procession of Magi to pay homage to Nero in Rome in AD 66.8 Thus a visit by the Magi to pay homage to Jesus, the new King of the Jews, would not have appeared as particularly unusual to readers of Matthew's gospel. However, the Magi must have had an

5Plato, The Republic, 529.

6Philo, De Opificio Mundi, 22. For a discussion of astronomy as an integral part of first century education see A. Mendelson, Secular Education in Philo of Alexandria (Cincinnati, Hebrew Union College Press 1982) 15-24.

${ }^{7}$ W.K.L. Clarke, The First Epistle of Clement to the Corinthians (London \& New York, Macmillan 1937).

8Suetonius, Nero 13 \& 30; Tacitus, Ann., 16:23: Dio Cassius, Hist., 63:1. 
unmistakably clear astronomical/astrological message to start them on their journey.

\section{Characteristics of the Star of Bethlehem}

There are several specific characteristics of the star of Bethlehem recorded in Matthew's gospel which, if accepted, allow the type of astronomical object to be identified uniquely. The characteristics are as follows:

(i) It was a star which had newly appeared. Matthew 2:7 states 'Then Herod summoned the Magi secretly and ascertained from them the exact time when the star had appeared'.

(ii) It travelled slowly through the sky against the star background. The Magi 'saw his star in the east' (Mt. 2:2) then they came to Jerusalem where Herod sent them to Bethlehem, then 'they went on their way and the star they had seen in the east went ahead of them' (Mt. 2:9). Since Bethlehem is to the south of Jerusalem the clear implication is that the star of Bethlehem moved slowly through the sky from the east to the south in the time taken for the Magi to travel from their country to Jerusalem, probably about one or two months (see p. 48).

(iii) The star 'stood over' Bethlehem. Matthew 2:9 records that the star 'went ahead of them and stood over the place where the child was'. Popular tradition has the star pointing out the very house, oikos (Mt. 2:11) in which Christ was born, but Matthew neither states nor implies this: according to him, viewed from Jerusalem the star stood over the place where the child was born, i.e. Bethlehem. ${ }^{9}$ If the above textual evidence is accepted then all but one of the astronomical objects suggested in the literature as the star of Bethlehem can be ruled out. For example, the most popular theory, demonstrated in many planetariums, is that the star of Bethlehem refers to a conjunction of Jupiter and Saturn in 7 BC. This planetary conjunction theory dates back to the 8 th century astronomer/astrologer Masha'allah ${ }^{10}$ and has been widely

${ }^{9}$ Cf. D.A. Carson, 'Matthew', The Expositor's Bible Commentary 8 (Grand Rapids, Zondervan Publishing House 1984) 88-9.

${ }^{10}$ E.S. Kennedy \& D. Pingree, The Astrological History of Masha'allah (Cambridge Mass., Harvard University Press 1971). 
supported in more recent times ${ }^{11}$ but it does not satisfy the description that the star was a single star which appeared at a specific time, nor of a star which 'stood over' Bethlehem. The next most popular theory is that the star was a nova or a supernova. The first suggestion that the star of Bethlehem was a nova was made by Foucquet in 1729 , and possibly earlier by Kepler in $1614^{12}$ and it has received considerable recent support. ${ }^{13}$ A nova or supernova satisfies the requirement that the star of Bethlehem was a single star which appeared at a specific time, but cannot account for the star moving through the sky. Similarly, all other suggestions for the star of Bethlehem (e.g. that it was Venus, etc.) can be ruled out except one: a comet.

\section{The Star of Bethlehem was a Comet?}

Comets probably have the greatest dramatic appearance of all astronomical phenomena. They can be extremely bright and easily visible to the naked eye for weeks or even months. Spectacular comets typically appear only a few times each century. They can move slowly or rapidly across the sky against the backdrop of stars, but visible comets usually move through the star background at about one or two degrees per day relative to the Earth. They can sometimes be seen twice, once on their way in towards perihelion (the point in their orbit which is closest to the sun) and again on their way out. However, from a given point on the Earth's surface, a comet is often only seen once, either on its way in or its way out, because of its orbit relative to the Earth. Since a comet usually peaks in brightness on its way out, about one week after perihelion, most visible comets are seen on their way out from perihelion.

${ }^{11}$ Hughes, op. cit. (1979); K. Ferrari-D'Occhieppo, 'The Star of the Magi and Babylonian Astrology', Chronos, Kairos, Christos: Nativity and Chronological Studies Presented to Jack Finegan, J. Vardaman \& E.M. Yamauchi (edd.) (Winona Lake, Eisenbrauns 1989) 41-53.

${ }^{12}$ A.J. Sachs \& C.B.F. Walker, 'Kepler's View of the Star of Bethlehem and the Babylonian Almanac for 7/6 BC', Iraq 46 (1984) 43-5.

${ }^{13}$ D.H. Clark, J.H. Parkinson \& F.R. Stephenson, 'An Astronomical ReAppraisal of the star of Bethlehem-A Nova in $5 \mathrm{BC}^{\prime}$, Quarterly Journal of the Royal Astronomical Society 18 (1977) 443-9. 
If the star described in Matthew was a comet, was it seen twice, first in the east on its way in towards perihelion and again in the south on its way out, or was it seen continuously moving from east to south (and then to west) on its way out? Matthew 2:9 states 'the star they had seen in the east went ahead of them [to Bethlehem in the south]'. It was not generally recognised 2000 years ago that a comet seen twice, once on its way in towards perihelion (where it would disappear in the glare of the sun) and again on its way out was one and the same comet. It was normally regarded as two separate comets. Since Matthew 2:9 clearly implies that the star seen in the south was the same star as that originally seen in the east we deduce that the star was continuously visible and suggest that it was a comet on its way out from perihelion travelling east to south (to west). In particular it is suggested that the Magi originally saw the comet in the east in the morning sky (see later). They travelled to Jerusalem, a journey time of 1-2 months (see later), and in this time the comet had moved through about $90^{\circ}$, from the east to the south, which is consistent with the 1 or 2 degrees per day typical motion of a comet. In Jerusalem, Herod's advisers suggested the Magi go to Bethlehem, six miles to the south and a journey time of one or two hours. The Magi set off next morning and saw the comet ahead of them in the south in the morning sky. Hence it appeared that the comet 'went ahead of' the Magi on this last lap of their journey.

The curious terminology in Matthew 2:9 that the star 'stood over' Bethlehem will now be considered. Phrases such as 'stood over' and 'hung over' appear to be uniquely applied in ancient literature to describe a comet, and I can find no record of such phrases being used to describe any other astronomical object. The historians Dio Cassius and Josephus were broadly contemporary with the author of Matthew's gospel. Dio Cassius $^{14}$ when describing the comet of 12 BC (Halley's comet) which appeared before the death of Marcus Agrippa wrote 'the star called comet stood for several days over the city [Rome]'. Josephus 15 states 'a star, resembling a sword, stood over the city [Jerusalem]', probably referring to the comet of AD 64

14Dio Cassius, Roman Hist. 54, 29.

15Josephus, BJ 15, 47. 
mentioned by Tacitus, 16 comets frequently being described as 'swords' in ancient literature because of their upward tails (in a direction away from the sun). Marcellinus describing a comet of $\mathrm{AD} 390$ writes 'a sign appeared in the sky hanging like a column and blazing for 30 days'.

Celestial objects (including comets) appear to move across the night sky because of the rotation of the earth. In addition, comets move against the backdrop of stars. What did Dio Cassius and Josephus mean when they referred to comets 'standing over' Rome and Jerusalem, respectively? At the time of Christ the prevailing theory of comets was due to Aristotle who had proposed that comets were sub-lunar objects located in the upper atmosphere. 17 This theory was consistent with the Aristotelian model of comets lying below the 'heavenly spheres' containing the Sun, Moon, planets and fixed stars, and presumably it also appeared to be consistent with visual observations of bright comets which often seem to be close to the Earth.18 Hence a comet is probably the only astronomical object to appear to be sufficiently low lying to be capable of satisfying the descriptions in Dio Cassius, Josephus and Matthew of a star standing over a particular town or city for part of the night. In addition, the upward tail of the comet would appear to point the head of the comet towards the city. Hence we interpret Matthew's description of a star 'standing over' the place where Jesus was born as meaning that when the Magi left Herod and headed towards Bethlehem, as he had suggested, they looked up and saw the comet in front of them, with a near vertical tail, the head of the comet appearing to stand over Bethlehem.

The use of the characteristic term 'stood over' by Dio Cassius and Josephus to describe a comet would seem to leave little doubt that when Matthew uses the term 'stood over' he is also describing a comet. Thus a comet uniquely fits the description in Matthew that the star was new, it travelled slowly through the star field from the east to the south, it went

16Tacitus, Ann. 6,5,3.

${ }^{17}$ See M.E. Bailey, S.V.M. Clube and W.M. Napier, The Origin of Comets (Oxford, Pergamon 1990).

${ }_{18}$ Many paintings and woodcuts of comets depict them as lying close to the Earth, see, for example, the contemporary impression of Donati's comet as seen over Paris on October 5, 1858 (Fig 1 in The World of Comets (Guillemin, Sampson Low 1877). 
ahead of the Magi, and 'stood over' Bethlehem, the place where the child was.

The identification of a comet with the star of Bethlehem goes back to Origen in the third century, and this is the earliest known theory for the star. Origen stated

The star that was seen in the East we consider to be a new star. . partaking of the nature of those celestial bodies which appear at times such as comets... If then at the commencement of new dynasties or on the occasion of other important events there arises a comet... why should it be a matter of wonder that at the birth of Him who was to introduce a new doctrine. . .a star should have arisen?19

In about $\mathrm{AD}$ 1303, Giotto painted a comet above the head of the infant Jesus in a fresco in the Arena Chapel in Padua, presumably using as a model the AD 1301 appearance of Halley's comet. ${ }^{20}$ The possibility that the star of Bethlehem was a comet has also more recently been suggested ${ }^{21}$ but without the detailed arguments given above and later.

If the evidence cited above for identifying the star of Bethlehem with a comet is so strong why has it not been previously considered in the detail given here? The main reason seems to be the widespread belief that a comet was regarded as a sign from heaven of impending calamity and divine displeasure. Hence, it is argued, if the star of Bethlehem was a comet, it could not possibly have been interpreted by the Magi as heralding the birth of the Messiah. However, an examination of historical records shows that comets were interpreted as heralding both good and bad major events, in particular the births and deaths of kings and important victories or defeats in wars. They were regarded as portents of major changes in the established order. Thus although a comet was regarded as a bad omen for the king who was about to die or for the side that was going to lose a war, equally a comet

${ }^{19}$ Origen, Contra Celsum, 1, 58.

20The European Space Agency mission to Halley's comet in 1985/6 was called 'Giotto' in commemoration of the artist's nativity comet.

${ }^{21} \mathrm{~J}$. Finegan, op. cit., H.W. Montefiore, 'Josephus and the New Testament', NovT 4 (1960) 139-60; N. Kokkinos, 'Crucifixion in AD 36: The Keystone for Dating the Birth of Jesus', in J. Vardaman \& E.M. Yamauchi (edd.), op. cit., 133-63; J. Vardaman in idem, op. cit., 55-82; A.I. Reznikov, 'La comète de Halley: une démystification de la légende de Noël?', Recherches d'astronomie historique 18 (1986) 65-8. 
was regarded as a good omen heralding a new king or a major victory for those on the winning side. Origen, following his suggestion that the star of Bethlehem was a comet, notes22 that comets are associated with both calamitous events and with great events and he refers to a book, Treatise on Comets, by Chaeremon the Stoic which lists occasions comets appeared when 'good was to happen'. The Chinese called comets 'broom stars' on account of their tails, and at least two ancient Chinese references make a pun of the word 'broom': a Chinese description of a comet of $524 \mathrm{BC}$ saw it as a 'new broom' to sweep away traditions and the old order of things, ${ }^{23}$ and Tsochhiu (c. $300 \mathrm{BC}$ ) stated 'a comet is like a broom, it signals the sweeping away of evil'.

In the second century $\mathrm{AD}$ the Roman historian Justinus quoted from an earlier Roman historian, who in turn quoted from the History of Kings of Timagenes of Alexandria, as follows:

Heavenly phenomena had also predicted the greatness of this man [Mithridates, the famous King of Pontus]. For both in the year in which he was born and in the year in which he began to reign a comet shone through both periods for 70 days in such a way that the whole sky seemed to be ablaze. ${ }^{24}$

This account was dismissed by many historians as legendary (cf. the star of Bethlehem) but Fotheringham ${ }^{25}$ identified comets in Chinese records in $134 \mathrm{BC}$ and $120 \mathrm{BC}$, precisely the already accepted years of the birth and accession to the kingship of Mithridates, and these comets are now accepted by historians as events confirming his chronology. Thus the assumed astrological significance of comets to ancient civilizations is clear: they were interpreted as portents of gloom and death for the established order, but they were equally regarded as heralds of victory in war and the birth of new kings who would change the existing order.

22Origen, Contra Celsum, 1, 59.

${ }^{23}$ N. Davidson, Astronomy and the Imagination (London \& New York, Routledge \& Keegan Paul 1985).

24Justinus, Pompei Trogi Hist. Phil. Epit. 37, 2, 1-3.

25J.K. Fotheringham, 'The new star of Hipparchus and the dates of birth and accession of Mithridates', Monthly Notices of the Royal Astronomical Society 79 (1919) 162-7. 
The Chinese kept careful astronomical records of visible comets, novae etc, and used different terms to describe them. 26 A tailed comet was called a sui-hsing, meaning a broom star, the 'broom' referring to the tail of the comet.27 A comet without a tail is called a po-hsing, and a nova is called a $\mathbf{k}^{\prime} \mathrm{o}-\mathrm{hsing}$, meaning guest-star. A clear distinction is not always made between novae and comets without a tail. Ho Peng-Yoke 28 lists and translates ancient Chinese records of comets and novae. Those appearing within the period $20 \mathrm{BC}$ to AD 10 are all described as comets and are given in Table 1. These objects are the only recorded astronomical phenomena appearing near the birth of Christ which satisfy the description in Matthew's gospel of a star that moved through the sky and that 'stood over' a place.

TABLE 1 Comets and novae appearing from $20 \mathrm{BC}$ to AD 10

\begin{tabular}{|c|l|c|}
\hline $\begin{array}{c}\text { Ho Peng-Yoke (1962) } \\
\text { catalogue number }\end{array}$ & \multicolumn{1}{|c|}{$\begin{array}{c}\text { Date } \\
\text { (Julian Calendar) }\end{array}$} & Description \\
\hline 61 & $\begin{array}{l}\text { 26 August 12 BC (for } \\
56 \text { days, Halley's } \\
\text { Comet) }\end{array}$ & po (comet) \\
\hline 63 & $\begin{array}{l}9 \text { March-6 April } \\
5 \text { BC (for over 70 days) }\end{array}$ & sui (tailed comet) \\
\hline 64 & April 4 BC & po (comet) \\
\hline
\end{tabular}

Note: (1) the catalogue of Ho Peng-Yoke (1962) also has a $10 \mathrm{BC}$ po comet as catalogue number 62. However, $C$. Cullen (to be published) has shown that there is no record of an appearance of a comet in that year but simply references to the one which had been seen in $12 \mathrm{BC}$.

Note: (2) the term sui (tailed comet) has traditionally been read as hui: see text.

The earliest possible date for the birth of Christ can be deduced from Luke 3:23, which states that he was 'about 30' when he started his ministry, which commenced with his baptism by John the Baptist. Luke 3:1-2 carefully states that the ministry of John the Baptist started in the fifteenth year of Tiberius Caesar. Depending on whether Luke used the Julian calendar or the Roman regnal year calendar, the fifteenth year

${ }^{26} \mathrm{M}$. Loewe, 'The Han view of comets', Bulletin of the Museum of Far Eastern Antiquities 52 (1980) 1-23.

27Traditionally the Chinese character read as sui has been read as hui, but sui is probably more correct, $\mathrm{M}$. Loewe, private communication.

${ }^{28}$ Ho Peng-Yoke, 'Ancient and mediaeval observations of comets and novae in Chinese sources', Vistas Astr 5 (1962) 127-225. 
of Tiberius was 1 Jan-31 Dec, AD 29 or autumn AD 28-29, respectively. The Lucan term 'about $30^{\prime}$ is a broad term covering any actual age ranging from 26 to 34,29 thus the earliest possible year for the birth of Christ is obtained by subtracting 34 years from $\mathrm{AD} 28$, giving $7 \mathrm{BC}$. Hence we can rule out as being too early for the star of Bethlehem the comet of $12 \mathrm{BC}$ (Halley's comet) in Table 1, although the $12 \mathrm{BC}$ comet has recently been revived as the star of Bethlehem. 30

The latest possible year for the birth of Christ is given by the date of the death of king Herod the Great, since Matthew 2:1 states that Herod was king when the star was seen by the Magi. The generally accepted date for the death of Herod the Great is the spring of $4 \mathrm{BC}^{31}$ although other dates have also been suggested (e.g. $5 \mathrm{BC}^{32}, 1 \mathrm{BC}^{33}$ and $\left.1 \mathrm{AD} .{ }^{34}\right)$ The evidence that Herod died in $4 \mathrm{BC}$ is strong and the accounts in Josephus of the reigns of his three sons, Archelaus, Antipas and Philip, all correlate perfectly with a 4 BC date. ${ }^{35}$ Josephus records that Herod died between an eclipse of the moon (usually taken to be that of 12/13 March $4 \mathrm{BC}$ ) and the following Passover (on 11 April 4 BC). 36 Josephus also describes that following the death of Herod his funeral occurred, then a seven-day mourning period, then demonstrations against his son Archelaus and then the Passover. Thus the latest date for the death of Herod is the end of March $4 \mathrm{BC}$ and hence the comet that appeared in April $4 \mathrm{BC}$ is too late to be the star of Bethlehem. In addition, the Chinese records give no details of the $4 \mathrm{BC}$ comet (e.g. its duration) hence it was probably short-lived and insignificant.

29P.L. Maier in Vardaman \& Yamauchi (edd.), op. cit., 113-30.

${ }^{30}$ Kokkinos, op. cit.; Vardaman, op. cit.; Reznikov, op. cit.

${ }^{31}$ E. Schürer, G. Vermes \& F. Millar, The History of the Jewish People in the Age of Jesus Christ (Edinburgh, T. \& T. Clark 1973) 1,326-8, n.165. 32T.D. Barnes, 'The Date of Herod's Death', JTS 19 (1968) 204-9.

${ }^{33}$ W.E. Filmer, 'The Chronology of the Reign of Herod the Great', JTS 17 (1966) 283-98; E.L. Martin, The Birth of Christ Recalculated (Foundation for Biblical Research, Pasadena 1980); O. Edwards, 'Herodian Chronology', PEQ 114 (1982) 29-42; idem, The Time of Christ (Edinburgh, Floris 1986).

34J.P. Pratt, 'Yet Another Eclipse for Herod', The Planetarium 19 (1990) 8-13.

35See also P.L. Maier in Vardaman \& Yamauchi (edd.), op. cit., 113-30; H.W. Hoehner in idem, op. cit., 101-11.

36Josephus, Ant. 17:167. 


\section{The Star of Bethlehem-a Comet in 5 BC}

Having effectively eliminated the comets of $12 \mathrm{BC}$ and $4 \mathrm{BC}$ as possible candidates for the star of Bethlehem, we note from Table 1 that the only possibility is the comet of $5 \mathrm{BC}$. The description of this in the Chinese Han shu, the official history of the former Han dynasty (206 BC-AD 9), on which Ho PengYoke depends, is as follows: 'Second year of the Chien-p'ing reign period, second month (5 BC, March 9-April 6), a suihsing appeared at $\mathrm{Ch}^{\prime}$ ien-niu for over 70 days'. The passage in the Han shu includes what is termed a traditional comment relating to this $5 \mathrm{BC}$ comet as follows:

Sui are the means of eliminating the old and inaugurating the new. $\mathrm{Ch}^{\prime}$ ien niu is the place whence the five planets arise, the origin of calendrical reckoning, the starting point of the three standards [of computation]. The appearance of the sui was a sign of change; the long period of its appearance was due to the importance of the incident [to come].

It appears from the above that the ancient Chinese regarded the $\mathrm{Ch}^{\prime}$ ien niu as an exceptionally important region of the sky: the origin in space of the five planets, the origin in time of a calendar and the origin of computational standards. Why was this? From ancient Chinese star maps it is clear that the $\mathrm{Ch}^{\prime}$ ien niu is the area of the sky including the constellation Capricornus. The 'five planets' were those known to astronomers 2000 years ago: Saturn, Jupiter, Mars, Venus and Mercury. ${ }^{37}$ The sun reaches it furthest point south of the equator on the Winter Solstice, 22 December, and from c. 1000 $\mathrm{BC}$ to c. AD 1000 this occurred when the Sun was in Capricornus. The latitude on Earth (23.5 south of the Equator) at which the Sun appeared overhead at noon on the Winter Solstice therefore became known as the Tropic of Capricorn. (Because of precession, the Winter Solstice is now in the neighbouring constellation of Sagittarius, but the Tropic of Capricorn retains its name). Writing about 2000 years ago, Manilius referred to this Tropic which 'marks the furthest station of the retreating Sun' 38 and he constructed a circle, 'held at the bottom by Capricornus' in which the five planets

37See, e.g., Manilius, Astronomica, (c. 30 BC-c. AD 30) 1, 532-538.

38Manilius, op. cit., 1, 582. 
moved.39 Thus to ancient astronomers Capricornus was of considerable significance and it is clear why the Chinese regarded it as the place of origin of the five planets, as the origin of a calendar based on the Winter Solstice (when the Sun was reborn) and as a starting point for computations. 40 Since the comet was observed for over 70 days it was almost certainly very bright for part of this time, as suggested in various ancient references to the star of Bethlehem. For example, the New Testament Apocryphal book ${ }^{41}$ the Protoevangelium of St James, possibly written in about AD 150, states that the wise men said 'we saw how an indescribably greater star shone among these stars and dimmed them'. The first reference identifying the $5 \mathrm{BC}$ object with the star of Bethlehem appears to be that of Foucquet in 1729,42 however he referred to the object as a nova, as did Lundmark ${ }^{43}$ and Clark et al.44 As we have argued earlier, the description in Matthew that the star moved from East to South is inconsistent with a nova. In addition, since the $5 \mathrm{BC}$ object was clearly described in the ancient Chinese records as a sui-hsing, and since the use of the term sui implies that the star had a definite tail, we should accept the Chinese description of this object as a tailed comet. 45 Further, the probability of a nova appearing in Capricornus, which has a high galactic latitude, is very small.

It is of interest to note that the Chinese records describe the $5 \mathrm{BC}$ comet as appearing in the area of the sky including Capricornus. In March/April Capricornus rose above the Eastern horizon as seen from Arabia and neighbouring countries and was first visible in the morning

${ }^{39}$ Manilius, op. cit., 1, 666-675.

40 See also Aratus, Phaenomena, 284 and 500, c. 275 BC and Lucretius, De Rerum Natura, 5.614, c.60 BC.

41M.R. James, The Apocryphal New Testament (Oxford, Clarendon 1924).

42J.F. Foucquet, Tabula Chronologica Historiae Sinicae (Rome, 1729).

${ }^{43} \mathrm{~K}$. Lundmark, 'The Messianic ideas and their astronomical background', VIIe Actes du Congrès International d'Histoire des Sciences (Jerusalem, 1953) 436-9.

44D.H. Clark, et. al., op. cit., 443-9.

45Private communication with Ho Peng-Yoke; see also C. Cullen, 'Can we find the Star of Bethlehem in Far Eastern Records?', Quarterly Journal of the Royal Astronomical Society 20 (1979) 153-9. 
twilight. Hence this particular comet would have been first seen rising in the East in the morning sky. Matthew 2:2 states that the Magi first saw 'his star in the East'. (An alternative translation of 'in the East' in 2:2 is 'at its rising'.) ${ }^{46}$ If this alternative translation is adopted the $5 \mathrm{BC}$ comet again fits the description, since according to the Chinese records it would be first seen at its rising in the East in the morning sky.

The Chinese records also describe the $5 \mathrm{BC}$ comet as being visible for over 70 days. The implication is that the comet was continuously visible, rather than being seen twice, once going in towards perihelion and again going out (see Section 4). The visibility for over 70 days is consistent with the probable journey time of the Magi (1-2 months, see later) and the probable time for the comet to move from east to south (45-90 days, see Section 4). Thus a consistent picture emerges: the Magi first saw the comet soon after perihelion in the east, in Capricornus, in the morning sky. They travelled to Jerusalem, a journey time of 1-2 months, and saw the comet in the south in the morning sky as they travelled from Jerusalem to Bethlehem. The comet continued to move to the west and became invisible after $70+$ days.

\section{The Three Signs in the Sky}

Why should this particular comet have caused the Magi to make their journey? It is suggested that a combination of three astronomical events was involved: the triple conjunction of Saturn and Jupiter in $7 \mathrm{BC}$, the massing of three planets in $6 \mathrm{BC}$ and finally the appearance of the comet in Capricornus in $5 \mathrm{BC}$. The eighth century $\mathrm{AD}$ astrological world history 'On Conjunctions, Religions and Peoples' by Masha'allah was based on an earlier Babylonian theory that important religious and political changes are predicted by conjunctions of the planets Saturn and Jupiter. ${ }^{47}$ Thus Masha'allah used Iranian astronomical computations to claim that the flood, the birth of Christ and the birth of Muhammad were all predicted by conjunctions of Saturn and Jupiter in the appropriate astrological circumstances. Rosenberg, ${ }^{48}$ following the

46D. Hughes, op. cit., (1979).

47 Kennedy \& Pingree, op. cit.

48R.A. Rosenberg, 'The "Star of the Messiah" Reconsidered', Biblica 53 (1972) 105-9. 
medieval Jewish writer Abarbanal,49 has explained how in Magian astrology the planet Saturn represented the divine Father and Jupiter was his son. The constellation Pisces was astrologically associated with Israel. Thus it is suggested that the astrological message of the conjunction of Saturn and Jupiter in Pisces in 7 BC was this: a Messiah-king will be born in Israel. The fact that the conjunction happened three times in 7 BC (in May, October and December) probably served to reinforce this message. In addition, Abarbanal in 1497 claimed that there was a conjunction of Saturn and Jupiter in Pisces in $1396 \mathrm{BC}$, three years before his assumed date of the birth of Moses. Thus it is suggested that the $7 \mathrm{BC}$ triple conjunction alerted the Magi to the coming of another Moses who would deliver his people: the Messiah.

Shortly after the triple conjunction of Saturn and Jupiter in 7 BC, Mars joined Jupiter and Saturn in the sky so that in February $6 \mathrm{BC}$ the three planets (still in Pisces) were separated by only about eight degrees. There is a tradition that the massing of these three planets preceded the birth of Christ. In 1465 Jakob von Speyer, the Court Astronomer for Prince Frederic d'Urbino, asked Regiomontanus 'Given that the appearance of Christ is regarded as a consequence of the Grand Conjunction of the three superior planets, find the year of his birth', a question that Regiomontanus was unable to answer.50 Both Jakob von Speyer and Regiomontanus were familiar with ancient Greek, Latin and Persian books on astronomy/astrology, 51 many of which have been lost, and the tradition that the massing of the three planets preceded the birth of Christ may be very early.

A similar massing was observed by Kepler in AD 1604 and, unlike Regiomontanus, he calculated that such massings of Jupiter, Saturn and Mars occurred only every 805 years, and suggested that they coincided with great events in history (his assumed dates were Moses $1617 \mathrm{BC}$, Isaiah $812 \mathrm{BC}$, Christ 6/7 BC, Charlemagne AD 799 and the Reformation AD 1604). For Kepler, the massing of the three planets was astrologically

49I. Abarbanal, The Wells of Salvation (1497).

$50 \mathrm{E}$. Zinner, Leben und Wirken des Joh. Müller von Königsberg, gennent Regiomontanus (Osnabrück, Otto Zeller 1968) ET E. Brown, Regiomontanus: His Life and His Work (London, Elsevier 1990).

51 Idem, op. cit. 
more important than the triple conjunction of Saturn and Jupiter, and he tentatively suggested that the supernova of AD 1604 , and the new star of $5 \mathrm{BC}$ might have resulted from these massings.52 To the Chaldeans, Mars represented the king of war, to the Persians the celestial warrior.53 Thus it is suggested that the massing of the three planets in $6 \mathrm{BC}$ following the triple conjunction in $7 \mathrm{BC}$ confirmed to the Magi that the Messiah-king to be born in Israel would be a mighty king. The scene was set: their expectations were aroused for a third sign which would indicate that the birth of the king was imminent.

\section{The significance of the $5 \mathrm{BC}$ Comet}

In the spring of $5 \mathrm{BC}$ a comet blazed forth in Capricornus. It has not previously been appreciated that this would have been rich in significance for the Magi. Ptolemy ${ }^{54}$ stated that the appearance of a comet in the orient (east) signified rapidly approaching events and in the occident (west) those that approach more slowly. The significance of the Magi seeing 'his star in the east' (Mt. 2:2) was therefore that it clearly provided the awaited sign that the birth of the king was imminent. Ptolemy further states that the significance of a comet is related to the part of the zodiac in which it appears. What was the likely significance to the Magi of a comet appearing in Capricornus? First, as has been shown, Capricornus was the place of the rebirth of the Sun. Second, in ancient astrology, each of the five planets had a zodiacal House that it ruled. Capricorn was the daytime House of Saturn,55 the divine Father in Magian astrology. The comet in Capricorn would therefore have provided the third and final sign of the birth of the divine son. To the Magi the repeated occurrence of the 'perfect' number three may also have been significant: a triple conjunction, then three planets massing and finally the third astronomical sign.

It may also be relevant to note that the Roman Emperor Augustus had a silver coin issued which bore the sign

52J. Kepler, De Vero Anno, (1614); Hughes, op. cit. (1979); Sachs \& Walker, op. cit.

${ }^{53}$ Davidson, op. cit.

54Tetrabiblos, $2,9$.

${ }^{55}$ See, e.g., Ptolemy, Tetrabiblos 1.4. 
of Capricorn, which is where the Moon stood at his birth on 23 September $63 \mathrm{BC}^{56}$ and Manilius extolled the greatness of Capricorn as Augustus' birth sign. 57 Capricornus means horned goat (Latin: caper $=$ goat and $\operatorname{corn} u=$ horn). In ancient times horns symbolised power and often symbolised kings. The writings of the Old Testament prophet Daniel may have been known to the Magi, since he wrote while in exile in Babylon (Dn. 1:1). Daniel had a vision of a horned goat which crossed the whole earth without touching the ground and which fought with and overcame a ram (Dn. 8:5-21). Various commentators have suggested that this vision may allude to Capricorn and Aries (the ram), and the horned goat, which Daniel identified with a mighty king of Greece, is usually taken to be the powerful king Alexander the Great. It is suggested that the remarkable sequence of the triple conjunction in $7 \mathrm{BC}$, the massing of three planets in $6 \mathrm{BC}$ and the comet in Capricornus in $5 \mathrm{BC}$ provided a very clear message to the Magi that a very great king was about to be born in Israel.

The Magi therefore set off and went to Jerusalem to King Herod, and asked 'where is the one who has been born king of the Jews' (Mt. 2:2). The legend that the star guided them to Jerusalem is not required (and Matthew neither states nor implies this): it is suggested that the Magi went to Jerusalem because their interpretation of the $7 \mathrm{BC}$ conjunction and the $6 \mathrm{BC}$ planetary massing was that a Messiah-king would be born in Israel, and the appearance of the $5 \mathrm{BC}$ comet told them this had happened. The religious advisers of Herod told them where: in Bethlehem, according to the prophet Micah. Again, they did not need guidance from the star, but were 'overjoyed' when, on this last lap of their journey, the star 'went before them' in the morning sky and when it 'stood over' Bethlehem, where Jesus was born. Bethlehem was a small town, and a few enquiries may have quickly revealed the location of the child recently visited by the shepherds.

Montefiore, 58 Finegan ${ }^{59}$ and Hughes 60 have previously suggested that the 'star' may have involved both the $7 \mathrm{BC}$

\footnotetext{
56Davidson, op. cit.

57Manilius, Astronomica, 2, 507.

${ }^{58}$ Montefiore, op. cit.

${ }^{59}$ Finegan, op. cit.

${ }^{60}$ Hughes, op. cit. (1976).
} 
conjunction and the $5 \mathrm{BC}$ or $4 \mathrm{BC}$ comets, with the Magi setting out in $7 \mathrm{BC}$ and arriving in Jerusalem in 5/4 BC. Hughes 61 has rightly criticised this theory as having the 'almost insurmountable difficulty' 62 that the star the Magi saw when they set out, and the star they saw in Jerusalem, should have been one and the same star not a conjunction and a star, since Matthew 2:9 states 'the star, which they saw in the East, went before them' on the final leg of their journey to Bethlehem. We agree: the proposal here is that two events, the conjunction of 7 $\mathrm{BC}$ and the planetary massing of $6 \mathrm{BC}$, alerted the Magi to the coming birth, but they did not set out until the 5 BC comet appeared in the east, indicating that the birth was imminent.

How long did their journey take? Hughes has noted that Lawrence of Arabia in The Seven Pillars of Wisdom states that in 24 hours a fully loaded camel can cover 100 miles if hard-pressed and 50 miles comfortably. 63 The furthest the Magi are likely to have travelled is from Babylon to Jerusalem, a distance of about 550 miles going directly across the Arabian desert and about 900 miles travelling via the Fertile Crescent. Allowing one or two months for the journey seems not unreasonable, so that if the Magi commenced their journey soon after the comet appeared in March/April $5 \mathrm{BC}$, they would have arrived in Jerusalem in April/June 5 BC. As noted in Section 5, this journey time for the Magi is consistent with the probable time for the comet to move from east to south and with the 70+ days visibility of the $5 \mathrm{BC}$ comet noted in the Chinese records.

The theory proposed here fits well with Herod giving orders to kill all the boys in Bethlehem who were two years old and under 'according with the time he had learned from the Magi' (Mt. 2:16). Earlier Herod had asked the Magi 'the exact time the star had appeared' (Mt. 2:7). It is suggested that the Magi spoke with Herod when they arrived in Jerusalem in April/June $5 \mathrm{BC}$ and recounted not only the appearance of the comet about one month previously but also described the significance of the planetary massing in $6 \mathrm{BC}$ and the triple conjunction of Jupiter and Saturn in May, October and December 7 BC. Herod, leaving nothing to chance, decided to

${ }^{61}$ Hughes, op. cit. (1979).

${ }^{62} \mathrm{He}$ has withdrawn his own earlier theory, Hughes, op. cit. (1976).

63Hughes, op. cit. (1979). 
kill all boys born since the first stage of the triple conjunction in May 7 BC, two years previously.

The $5 \mathrm{BC}$ date for the star of Bethlehem also fits well with the textual evidence for the length of stay of Jesus and his family in Egypt. According to Matthew 2:13-15, after the Magi had left Bethlehem, Joseph was warned that Herod planned to kill Jesus, so the family left for Egypt (a classic refuge for those trying to flee the tyranny of Palestine) and returned after Herod died. Both Origen and Eusebius state that Jesus and his family were in Egypt for two years and they returned in the first year of the reign of Archelaus. Archelaus, one of Herod's sons, started his reign when Herod died. Thus if Herod died at the end of March $4 \mathrm{BC}$, the first year of the reign of Archelaus was from April $4 \mathrm{BC}$ to April $3 \mathrm{BC}$. Jesus and his family probably left for Egypt shortly after the Magi left Bethlehem, in about April-June 5 BC. If they stayed in Egypt a reasonable time after the death of Herod, to be absolutely sure of the news, they could have returned to Israel in, say, March 3 BC, when travelling conditions would be good, in the first year of Archelaus and having spent about two years in Egypt. Thus the 5 BC comet is consistent chronologically with both Herod's massacre of the infants and the two year stay in Egypt.

\section{The Clue of the Census}

According to Luke 2:1-5, a census was taken by Emperor Caesar Augustus around the time of the birth of Christ, and Joseph travelled with Mary from Nazareth to his home town of Bethlehem in order to register. This census is one of the thorny problems of the New Testament about which much has been written. There are three well-documented censuses conducted by Augustus: in $28 \mathrm{BC}, 8 \mathrm{BC}$ and AD 14, but these were apparently only for Roman citizens. In addition, there are various records of provincial censuses under Augustus for non-citizens for purposes of taxation, for example in AD 6, a decade after the death of Herod the Great, Josephus refers to a census in Judea administered by Quirinius the governor of Syria, and Luke also refers to this census (Acts 5:37). However, there is no record of a census for taxation purposes in Judea around the time of the birth of Christ, hence the problem in interpreting Luke 2:1-5. 
The problem can be resolved if the census was not for taxation purposes but was instead a census of allegiance to Caesar Augustus. The fifth century historian Orosius states,

[Augustus] ordered that a census be taken of each province everywhere and that all men be enrolled. So at that time, Christ was born and was entered on the Roman census list as soon as he was born. This is the earliest and most public acknowledgement which marked Christ as the first of all men and the Romans as lords of the world. . . since in this one name of Caesar all the peoples of the great nations took oath, and through the participation in the census, were made part of one society. 64

Josephus appears to refer to the same event: 'when all the people of the Jews gave assurance of their goodwill to Caesar, and to the king's government, these very men [the Pharisees] did not swear, being above six thousand.'65 From the context of Josephus' words, this census of allegiance to Augustus occurred about one year before the death of Herod the Great.

There is one further problem with this census. Luke 2:2 is usually translated, 'This census was first made when Quirinius was governor of Syria', but Quirinius did not become governor of Syria until AD 6. However, the Greek sentence construction of Luke 2:2 is unusual and an alternative translation is: 66 'This census took place before the one when Quirinius was governor of Syria'. As noted above, from

64Orosius, Adv. Pag. 6, 22,7, 7, 2,16.

65Josephus, Ant, XVII, ii, 4.

${ }^{66}$ E.g. R.E. Brown, The Birth of the Messiah (London, Chapman 1977); this rendering, which can be traced back to J.G. Herwartus, Novae, verae, et exacte ad calculum astronomicum revocatae Chronologiae (Munich, 1612), has been maintained in the present century by M.J. Lagrange, 'Où en est la question du récensement de Quirinius?' $R B$ n.s. 8 (1911) 60ff. citing A. Calmet, H.A. Wallon, G.P.E. Huschke, K. Wieseler, H. Ewald and C.P. Caspari for this interpretation, F.M. Heichelheim in An Economic Survey of Ancient Rome, ed. T. Frank, 4 (Baltimore, 1938), 160 ff.; N. Turner, Grammatical Insights into the New Testament (Edinburgh, 1965), 23 f., and A.J.B. Higgins, 'Sidelights on Christian Beginnings in the Graeco-Roman World', EQ 41 (1969) 197ff. For a critique of this new rendering, and for several other points of relevance, see G. Ogg, 'The Quirinius Question Today', ExT 79 (196768) $231 \mathrm{ff}$ cited by F.F. Bruce in his full discussion of the epigraphic and literary evidence endorses the alternative rendering in 'Quirinius' edd. A.R. Millard and B.W. Winter, Documents of New Testament Times (forthcoming Apollos Press). 
Josephus this latter census can be dated to AD 6, and Luke (Acts 5:37) was well aware of it. Thus the earlier census referenced by Luke in Luke 2:1-5 provides a chronological clue to the birth of Christ, and from the context in Josephus 67 this census of allegiance occurred about 1 year before the death of Herod the Great, which is consistent with our placing the birth of Christ in the spring of $5 \mathrm{BC}$.

\section{A New Chronology for the Life of Christ}

What is the earliest date for the birth of Jesus? It would seem that the Magi expected Jesus to be born shortly after the time the $5 \mathrm{BC}$ comet appeared since a comet appearing in the east signified an imminent event, and when they arrived in Jerusalem they asked Herod, 'Where is the one who has been born king of the Jews?' (Mt. 2:2). Hence it would seem that the earliest possible date for the birth of Jesus is when the comet first appeared, and the earliest date for this according to the Chinese records is 9 March $5 \mathrm{BC}$. This is consistent with Luke 2:8 which states that at the time of the birth of Jesus 'there were shepherds living out in the fields nearby, keeping watch over their flock by night'. Bethlehem is cold and very wet during December, January and February and flocks of sheep were not normally kept in the fields in these months.68 Sheep were usually put out to grass between March and November, the shepherds being with the flocks at night particularly during the spring lambing season (March-April).

An approximate latest date for the birth of Jesus can be deduced as follows. According to Luke 2:22, after the birth and following a time of purification, Joseph and Mary took Jesus to the temple in Jerusalem. Leviticus 12:2-4 specifies that the time of purification for the mother of a male child is 40 days, after which she can come to the temple. Assuming one day for travel from Bethlehem to Jerusalem (a distance of 6 miles), Jesus would have been born not less than six weeks before the visit of the Magi. (Since Jesus and his family left for Egypt shortly after the visit of the Magi the most probable sequence of events in the Matthew/Luke birth narratives is birth, visitation of the shepherds, presentation at the temple in Jerusalem, return to Bethlehem, visit of the Magi.) There was no point in Joseph

67Josephus, Ant, 17, 2, 4.

${ }^{68}$ Hughes, op. cit. (1979). 
and Mary staying in Bethlehem after the purification and visit to the temple since they had originally only gone to Bethlehem for the census. Hence it is reasonable to assume the Magi visited Jesus very shortly after his return from the temple to Bethlehem. This is consistent with the comet being visible for 70 days and the one to two month journey time of the Magi.

The Chinese records state that the comet first appeared sometime in the period 9 March to 6 April $5 \mathrm{BC}$ and lasted over 70 days. Thus the latest date for the Magi to have seen the 'star' at Bethlehem was 6 April plus 70 days, i.e. 15 June, and the latest date for the birth of Jesus is this date minus six weeks, i.e. 4 May. If this evidence is accepted, Jesus was born sometime in the period 9 March-4 May $5 \mathrm{BC}$, which is consistent with the Lucan shepherd reference. The most likely date for the Baptism of Jesus is autumn AD 2969. If Jesus was born in the Spring of $5 \mathrm{BC}$ then he would have been 33 when he commenced his ministry. This is consistent with Luke 3:23 that he was 'about thirty' at this time. (As noted above, the Greek translated 'about thirty' means any age between 26 and 34). If the crucifixion was on 3 April AD 33,70 then Jesus was around his 37th birthday when he died.

We have deduced that Jesus was born in the spring of 5 $\mathrm{BC}$. We note that in $5 \mathrm{BC}$ the first day of the feast of Passover (Nisan 15 in the Jewish calendar) fell on 20 April and we tentatively give several reasons which suggest that Jesus may have been born around Passover time. At Passover time all adult males were required to come to Jerusalem, hence Jerusalem and its neighbourhood were extremely crowded and nearby Bethlehem would be very crowded too. Censuses were not held on a particular day but were spread over a period of time and it is suggested that Joseph chose to visit Bethlehem for the census at the same time as Passover to save an extra journey. Thus the inn was full (Lk. 2:7) because it was the time of a feast ${ }^{71}$ in particular the feast of Passover. ${ }^{72}$ Josephus ${ }^{73}$

${ }^{69}$ Finegan, op. cit.; Maier, op. cit.

${ }^{70}$ C.J. Humphreys \& W.G. Waddington, 'Dating the Crucifixion', Nature 306 (1983), 743-6; O. Edwards, The Time of Christ (Edinburgh, Floris 1986); Hoehner, op. cit.

${ }^{71} \mathrm{G}$. MacKinlay, The Magi, How they recognised Christ's Star (London, Hodder \& Stoughton 1897).

72 See also Pratt, op. cit., who dates the Nativity to Passover, 1 BC.

73Josephus, BJ, 1, 229; 6, 270. 
states that pilgrims came up to Jerusalem about a week before Passover to undergo the appropriate purificatory rites, and the feast itself lasted for one week. Thus it is tentatively suggested that the birth of Jesus may have occurred in the week before or after Passover in 5 BC, i.e. in the period 13-27 April 5 BC.

Birth at Passover time is consistent with Jewish expectations for the birth of the Messiah. For example, the Jewish scholar Abarbanal, c. AD 1497 and still expecting the Messiah, states that the messianic redemption will come in the month Nisan since the 'cup of Elijah' at the Passover meal preserves the symbolism that the new redemption will come during the same season as the Exodus from Egypt. A further clue may be provided by the words of John the Baptist near the time of the baptism of Christ. He twice greets Jesus with the words 'The Lamb of God' (Jn. 1:29, 36) and commentators have discussed the background of this strange phraseology. If Jesus was born at Passover time, particularly if he were born on 10 Nisan (sunset Sunday 14 April to sunset Monday 15 April in 5 BC) when the Passover lambs were chosen, without spot or blemish, John would have a clear reason to call him the Lamb of God. Some key dates and date ranges in the chronology of the early life of Jesus are listed below.

TABLE 2 Chronology of the Early Life of Jesus

\begin{tabular}{|l|l|}
\hline \multicolumn{1}{|c|}{ Date in Julian Calendar } & \multicolumn{1}{c|}{ Event } \\
\hline $\begin{array}{l}\text { 9 March-4 May 5 BC } \\
\text { (13-27 April 5 BC) }\end{array}$ & Birth of Jesus in Bethlehem \\
\hline $\begin{array}{l}\text { 9 March-4 May 5 BC } \\
\text { (13-27 April 5 BC) }\end{array}$ & Visit of the Shepherds \\
\hline $\begin{array}{l}\text { 16 March-11 May 5 BC } \\
\text { (20 April-4 May 5 BC) }\end{array}$ & $\begin{array}{l}\text { Circumcision on the eighth day } \\
\text { (counting inclusively) }\end{array}$ \\
\hline $\begin{array}{l}\text { 18 April-15 June 5 BC } \\
\text { (22 May-6 June 5 BC) }\end{array}$ & $\begin{array}{l}\text { Presentation of Jesus at the } \\
\text { Temple in Jerusalem after 40 days } \\
\text { from birth then return to } \\
\text { Bethlehem }\end{array}$ \\
\hline $\begin{array}{l}\text { 20 April-15 June 5 BC } \\
\text { (24 May-8 June 5 BC) }\end{array}$ & Visit of the Magi \\
\hline $\begin{array}{l}\text { late April/mid June 5 BC } \\
\text { (late May/mid June 5 BC) }\end{array}$ & Flight to Egypt \\
\hline end March 4 BC & Death of Herod \\
\hline ? March 3 BC & Return from Egypt to Nazareth \\
\hline
\end{tabular}

Note: The dates given in brackets are narrower date ranges based on Jesus being born around Passover time (see text). 


\section{The Date of Christmas}

The traditional Western date of Christmas, 25 December, first occurs in the Roman calendar Chronographus Anni CCCLIIII (Chronographer of the Year 354). In this calendar the sequence of festivals in the church year begins with the festival of the birth of Christ on 25 December. The original version of this calendar may date back to AD 336, hence it is not particularly early. ${ }^{74}$ The pagan feast of the sol invictus (the invincible sun) was observed on 25 December since it was the date accepted at the time for the winter solstice. The Christian festival of Christmas essentially replaced this pagan festival. The traditional Eastern date of the birth of Christ is 6 January. Epiphanius (Panarion haer. 51, 22, 9-11) states that this was the date of the pagan festival of Kore which the Christian festival then replaced.

However, the actual birth of Christ was unlikely to have been in winter if we accept Luke 2:8 'there were shepherds living out in the fields nearby, keeping watch over their flock at night'. We very tentatively suggest how 25 December and 6 January might have been chosen for the birth of Christ. According to the present paper, Christ was born in the Spring. We suggest that this birth date may have been confused with the date of the conception (and Epiphanius comments on such a confusion in the early church). Adding nine months for the pregnancy leads to a date range close to the existing pagan festivals of Kore and the sol invictus which were then taken over to be Christmas.

\section{Conclusions}

The Magi are well known in classical literature as a religious group who were skilled in the observation and 'interpretation' of the stars. At the time of Christ they lived mainly in Persia, Mesopotamia and Arabia (now Iran, Iraq and Saudi Arabia, respectively) and they are known to have visited kings in other countries. It is therefore consistent with our knowledge of the Magi that an astronomical sign could have led them to visit a new king.

There are three main characteristics of the star of Bethlehem recorded in Matthew: it was a star which had

74Finegan, op. cit. 
newly appeared, it travelled slowly through the sky against the star background, and it stood over Bethlehem. It is suggested in this article that one, and only one, astronomical object satisfies this description: a comet. It is proposed that the Magi originally saw this comet in the east in the morning sky. They travelled to Jerusalem, a journey time of 1-2 months, and in this time the comet had moved to the south in the morning sky, hence it appeared ahead of them as they travelled from Jerusalem to Bethlehem on the last lap of their journey. The comet appeared to stand over Bethlehem with a near vertical tail. It is shown that the description 'stand over' is uniquely applied in ancient literature to refer to a comet.

From ancient Chinese astronomical records three comets are possible candidates for the star of Bethlehem, those of $12 \mathrm{BC}, 5 \mathrm{BC}$ and $4 \mathrm{BC}$. It is shown from historical and biblical evidence that the comets of $12 \mathrm{BC}$ and of $4 \mathrm{BC}$ were too early and too late, respectively, to be the star of Bethlehem. Hence the comet of $5 \mathrm{BC}$ may uniquely be identified as the star of Bethlehem. The Chinese description of this comet, particularly its appearance in the east and its visibility for over 70 days, is consistent with the description in Matthew.

It is suggested that a combination of three unusual and significant astronomical events caused the Magi to set off on their journey. First there was a triple conjunction of Saturn and Jupiter in the constellation Pisces in 7 BC. Such an event occurs only every 900 years. The probable astrological significance of this event to the Magi was that a divine king would be born in Israel. Second, in $6 \mathrm{BC}$ there was a massing of the three planets Mars, Saturn and Jupiter in Pisces. Such a massing only occurs every 800 years (and very much more infrequently in Pisces) and it would have confirmed to the Magi that the king to be born in Israel would be a mighty king. Third, a comet appeared in $5 \mathrm{BC}$ in the east in the constellation Capricornus. In the astrology of the times a comet in the east signified a rapidly approaching event. The comet was therefore the third and final sign which caused the Magi to set off on their journey. It is shown that the probable significance of the comet in Capricornus to the Magi was also that a very great king was about to be born.

Further analysis suggests that the birth of Christ was in the Spring, in the period 9 March-4 May 5 BC. Tentatively 
the period around Passover time is suggested (13-27 April 5 $B C)$. This date is consistent with the available evidence including a reference in Luke to there being shepherds out in the fields at night. Although today Christmas is celebrated on 25 December in the west and on 8 January in the east, we suggest that the evidence of astronomy, the bible and other ancient literature points to the Spring of $5 \mathrm{BC}$ as being the time of the first Christmas.

It is proposed to continue the discussion of the chronology of the life of Christ in 'The Jewish Calendar, a Lunar Eclipse and the Date of Christ's Crucifixion' in volume 43.2 (November, 1992). 